\title{
The Moving Centre: Preferences for Government Activity in Britain, 1950-2005
}

\author{
JOHN BARTLE, SEBASTIAN DELLEPIANE-AVELLANEDA AND \\ JAMES STIMSON*
}

The political 'centre' is often discussed in debates about public policy and analyses of party strategies and election outcomes. Yet, to date, there has been little effort to estimate the political centre outside the United States. This article outlines a method of estimating the political centre using public opinion data collected for the period between 1950 and 2005. It is demonstrated that it is possible to measure the centre in Britain, that it moves over time, that it shifts in response to government activity and, furthermore, that it has an observable association with general election outcomes.

The fundamental driving forces in democracy are the preferences of citizens across a wide range of issues. These preferences, together with other factors, influence the decisions of individual voters. Elections aggregate those individual preferences, however imperfectly, into collective choices. The aggregation of preferences across issues and across individuals, therefore, lies at the very heart of the democratic process. ${ }^{1}$ And since electoral choices are structured by political parties that tend to compete primarily along a single left-right dimension relating to the scope of government activity, it is just a small step to arguing that these preferences can be summarized by a measure of central tendency such as the 'typical', 'average', 'mean', 'median' or 'political centre'.

The political centre is a concept of enormous political importance. Political theorists maintain that, if politics is unidimensional, the median voter is the 'Condorcet winner' in the sense that a policy package that suits this individual would defeat all others in a

* Department of Government, University of Essex (email: jbartl@essex.ac.uk); School of Politics, University College Dublin; and Department of Political Science, University of North Carolina, Chapel Hill, respectively. The authors would like to thank Hershbinder Mann for collecting much of the early Gallup data. This project was funded by ESRC award number 00-22-2053. Earlier versions of this article were presented at the ECPR General Conference, Pisa, 2007 and the MPSA, Chicago, 2008. The authors also thank James Adams, Judith Bara, Malcolm Brynin, Evelyn Bytzek, Ian Budge, Lawrence Ezrow, Jane Green, Samantha Laycock, Anthony McGann, Hershbinder Mann, Samuel Merrill, Thomas J. Quinn, David Sanders, Elinor Scarbrough, Thomas J. Scotto, Stuart Soroka, Vera Troeger, Hugh Ward, Paul Whiteley and Chris Wlezien for their helpful comments and suggestions, and are particularly grateful to Frances Lynch of the University of Westminster for generously supplying data on average income tax levels.

${ }^{1}$ Philip E. Converse, 'Popular Representation and the distribution of information', in John A. Ferejohn and James H. Kuklinski, eds, Information and Democratic Processes (Urbana and Chicago: University of Illinois Press, 1990).

${ }^{2}$ Ian Budge, Hans Dieter Klingemann, Andrea Volkens, Judith Bara and Eric Tanenbaum, Mapping Policy Preferences: Estimates for Parties, Electors, and Governments 1945-1998 (Oxford: Oxford University Press, 2001); Hans Dieter Klingemann, Andrea Volkens, Judith Bara, Ian Budge and Michael P. MacDonald, Mapping Policy Preferences: Estimates for Parties, Electors, and Governments in Eastern Europe, European Union, and OECD 1990-2003: Vol. 2 (Oxford: Oxford University Press, 2006). 
series of pairwise contests. ${ }^{3}$ Analytical political scientists, moreover, argue that if party competition takes place along a single dimension, office-seeking parties will occupy the same position as the median voter at the centre. ${ }^{4}$ Where policy is the only basis for choice, the party that wins the support of the median voter will win the election. But even when there are other non-policy factors in play, such as partisanship or valence issue advantages, the party that occupies the centre ground is advantaged in the competitive struggle for the vote..$^{5}$ The centre is also of direct significance to politicians and parties that compete for office. Not only does being at the centre produce electoral advantages, it has a special moral significance too. Unsurprisingly, almost every electoral politician feels the need to stake some claim to the centre ground. ${ }^{6}$ Indeed, the very declaration that a politician or party occupies the centre ground appears to carry with it an implicit promise that they will represent (and respond to) the preferences of the electorate.

Democracy is said to be uniquely virtuous because it is the only system in which there is a necessary relationship between the preferences of voters and public policy. ${ }^{7}$ Nevertheless, citizen preferences are also undoubtedly influenced by the activities of government itself and - since government policy changes - they also change over time. Christopher Wlezien's 'thermostatic' model of political preferences, for example, suggests that the electorate has a preferred (or ideal) policy point in relation to specific policy domains. ${ }^{8}$ When the government spends 'too little', demand for additional expenditure increases and, when it spends 'too much', the demand for additional expenditure declines. Public preferences respond 'thermostatically' (i.e., move in the opposite direction) to government policy. This model has been handsomely corroborated in Christopher Wlezien's and Stuart Soroka's studies of expenditure and public preferences in specific policy domains (such as defence, health, education and roads) in Britain. ${ }^{9}$ The model can, however, be generalized across the whole of government and leads to the expectation that the political centre will itself move over time in response to government activity. It might be supposed, for example, that as the need for government activity increases (as unemployment rises or the quality of public services declines), the electorate might begin to prefer greater activity and move on average to the left. ${ }^{10}$ Similarly, as inflation

3 Anthony McGann, The Logic of Democracy: Reconciling equality, Deliberation and Minority Protection (Ann Arbor: University of Michigan Press, 2006), chap. 2.

4 Anthony Downs, An Economic Theory of Democracy (New York: Harper \& Row, 1957); Samuel Merrill III and Bernard Grofman, A Unified Theory of Voting: Directional and Proximity Spatial Models (Cambridge: Cambridge University Press, 1999).

5 James Adams, Samuel Merrill and Bernard Grofman, A Unified Theory of Party Competition: A Cross-National Analysis Integrating Spatial and Behavioural Factors (Cambridge: Cambridge University Press, 2005).

6 See Gordon Pascoe-Watson, 'No left turns for deputy PM', Sun, 31 May 2007; and David Cameron speech 'We Stand for Social Responsibility', 1 October 2006, http://www.conservatives.com/ tile.do?def=news.story.page\&obj_id=132485.

7 John D. May, 'Defining Democracy: A Bid for Coherence and Consensus', Political Studies, 26 (1978), 1-14.

${ }^{8}$ Christopher Wlezien, 'The Public as Thermostat: Dynamics of Preferences for Spending', American Journal of Political Science, 39 (1995), 981-1000; Christopher Wlezien, 'Patterns of Representation: Dynamics of Public Preferences and Policy', Journal of Politics, 66 (2004), 1-24.

${ }^{9}$ Stuart N. Soroka and Christopher Wlezien, 'Opinion-Policy Dynamics: Public Preferences and Public Expenditure in the United Kingdom', British Journal of Political Science, 35 (2005), 665-89.

${ }^{10}$ Robert S. Erikson, Michael B. Mackuen and James A. Stimson, The Macro Polity (Cambridge: Cambridge University Press, 2002). 
increases and taxes rise due to increased government activity, the electorate might prefer less government activity and move on average to the right. These movements in the political centre may eventually feed through into the choices of the electorate. Indeed, if this stylized model were true, it would provide the basis for a parsimonious explanation as to why the major parties have alternated in power in the post-war period.

The concept of the political centre is central to general theories and general models of electoral competition, election outcomes and citizen preferences. To date, however, many of these hypotheses have gone untested. The reasons for this are simply stated. The raw materials that are necessary to measure 'average' public preferences - survey evidence about mass opinion - are in short supply until the mid to late 1960s when the commercial polling industry expanded and social scientific studies, such as the British Election Study, were established. ${ }^{11}$ Yet even when survey evidence is more plentiful in this later period, the data collected often do not relate to preferences about government activity of the sort associated with the left-right dimension. And even when the data do touch on these issues, the relevant questions are rarely repeated in precisely the same form, making it difficult to infer whether specific preferences actually have changed, let alone whether they have moved to the left (in favour of more government activity) or to the right (in favour of less government activity). Despite the best endeavours of many fine political scientists, therefore, movements in the political centre have gone unmeasured and the field has largely been left to historians who make informed speculations about the ebb and flow of public opinion. ${ }^{12}$

To date, the only systematic attempt to estimate the political centre has taken place in the United States. ${ }^{13}$ This research has demonstrated that, despite the existence of similar data problems, it is possible to track changes in the political centre, that these changes respond to changes in unemployment and inflation, that the distance between the average voter and presidential candidates has a sizeable effect on election outcomes between 1948 and 1996 and, finally, that policy outcomes respond to prior movements in these preferences. ${ }^{14}$ In this article, we build on these studies by replicating the methodology of estimating the 'policy mood' in Britain and by making use of data on public preferences collected between 1950 and 2005. Our findings provide corroboration for these US studies. We show that it is possible to measure the political centre in Britain; that the political centre moves over time, that the centre responds thermostatically to government activity and, furthermore, that it appears to have an observable association with general election outcomes. These 'macro-level' findings provide an interesting analytic counterpoint to the standard 'micro-studies' of British general elections.

${ }^{11}$ See Frank Teer and James D. Spence, Political Opinion Polls (London: Hutchinson, 1973); Robert M. Worcester, British Public Opinion: A Guide to the History and Methodology of Political Opinion Polling (Oxford: Basil Blackwell, 1991); Robert M. Worcester, 'Pollsters, the Press, and Political Polling in Britain', Public Opinion Quarterly, 44 (1980), 548-66; Robert M. Worcester, 'The Polls: Britain at the Polls, 1945-1983', Public Opinion Quarterly, 48 (1984), 824-33.

12 David Sanders, 'The Impact of Left-Right Ideology', in Geoffrey Evans and Pippa Norris, eds, Critical Elections: British Parties and Voters in Long-Term Perspective (London: Sage, 1999), pp.181-206; Hugh Ward, 'Preference Shaping and Party Competition: Some Empirical and Theoretical Arguments', in Judith Bara and Albert Weale, eds, Democratic Politics and Party Competition (London: Routledge, 2006), pp. 245-70.

13 James Stimson, Public Opinion in America: Moods, Cycles and Swings. (Boulder, Colorado: Westview, 1999); James Stimson, Tides of Consent: How Public Opinion Shapes American Politics. (Cambridge: Cambridge University Press, 2004).

${ }^{14}$ James A. Stimson, Michael B. Mackuen and Robert S. Erikson. 'Dynamic Representation', American Political Science Review, 89 (1995), 543-65; Erikson et al. The Macro Polity. 
THE CONCEPTS OF THE POLICY MOOD AND THE POLITICAL CENTRE

The key concept in US studies is labelled 'policy mood'. This concept is based on the general proposition that aggregation of variables cuts out inessential detail and allows analysts to examine the systemic relationships between preferences and policy and between policy and preferences. Somewhat more directly, however, it is inspired by Walter Lippmann's observation that 'since out of drift and incoherence, settled aims do appear, there must be a mysterious contrivance at work somewhere over and above the inhabitants of a nation. They invoke a collective soul, a national mind, a spirit of the age which imposes order upon random opinion.' 15

The suggestion that 'settled aims' emerge among the public is equally familiar to analysts of public policy. John Kingdon, for example, has observed:

People in and around government sense a national mood. They are comfortable discussing its content and believe that they know when the mood shifts. The idea goes by different names ... But common to all ... is the notion that a rather large number of people out in the country are thinking along certain lines, that this national mood changes from one time to another in discernible ways, and that these changes in mood or the climate have important impacts on policy agendas and policy outcomes. ${ }^{16}$

If policy makers can sense variations in 'mood', we should also be able to find some traces of this among the mass public's responses to the many individual responses to survey questions. This proposition is supported by modern theories of survey response such as John Zaller's Receive-Accept-Sample (RAS) model. ${ }^{17}$ This model challenges the assumption that respondents have fully worked-out opinions on specific issues. Instead, it suggests that responses to questions in specific domains - or on highly specific issues in specific domains - may be based on a small number of general considerations. Since we know from other sources, such as the analyses of the Manifesto Research Group, that parties tend to structure issues in terms of left and right, it seems plausible to suggest that responses to a wide range of survey questions might well reflect the enduring debate about the scope of government activity or what is usually called the left-right dimension. ${ }^{18}$ If preferences that relate to these issues are measured over time, then variations in these preferences should reflect variations in this underlying (or latent) variable. And if we could somehow infer this latent variable, we could see how it varies over time. This is the simple intuition on which previous US research is based.

The concept of 'the policy mood' is now widely used in studies of American public opinion and is one of the central variables in The Macro Polity, which is the most ambitious systemic model of the American political system produced to date. ${ }^{19}$ Yet though the term 'mood' has now entered into the political science lexicon, we prefer not to use it here. This is simply because, while mood is appropriate in the context of policy

\footnotetext{
${ }_{15}^{15}$ Walter Lippmann, Public Opinion (New York: Free Press, 1997), p. 127.

16 John W. Kingdon, Agendas, Alternatives and Public Policy (Boston, Mass.: Little Brown, 1984), p. 153. See also George Orwell, Orwell: The Observer Years (London: Atlantic Books, 2004), pp. 4-5.

${ }^{17}$ John R. Zaller, The Nature and Origins of Mass Opinion (Cambridge: Cambridge University Press, 1992). See also James A. Stimson, 'The Micro Foundations of Mood', in James H. Kuklinski, ed., Thinking about Political Psychology (Cambridge: Cambridge University Press, 2002), pp. 253-80.

${ }^{18}$ Ian Budge, 'Identifying Dimensions and Locating Parties: Methodological and Conceptual Problems', in Richard S. Katz and William Crotty, eds, Handbook of Party Politics (London: Sage, 2006), pp. $422-34$.

${ }^{19}$ Erikson et al., The Macro Polity.
} 
analysis, it has unfortunate connotations of transient or superficial sentiment or emotions. The word 'mood' hardly seems appropriate to describe something that is thought - at least by some - to be the fundamental driving force of democratic politics. Therefore, we prefer to use the term 'preferences' to underline the relationship between this variable and other important variables such as vote shares and public policy. ${ }^{20} \mathrm{We}$ use the term 'political centre' to describe the mean value of this variable and we expect to find that this varies over time.

The outline of the argument is relatively simply stated but the measurement or estimation of the political centre is far more difficult, since it requires a large amount of data and a prodigious amount of computational effort. In the next section, we examine the data that provide the basis for our estimate, and in the following section we explain how the algorithm uses this evidence to extract the latent variable.

\section{DATA}

At first sight, the term 'the political centre' appears to illustrate perfectly Converse's proposition 'that those things that are important to study cannot be measured and what can be measured does not really matter'. ${ }^{21}$ Yet without some operational indicator, the concept of the centre remains a verbal sticking plaster to conceal our ignorance. In this article, we estimate the centre using all the available evidence collected since 1950 about longitudinal covariation in public preferences. We use an algorithm modelled on principal components analysis to extract the latent common component. Such bald statements, however, conceal a great deal. The following subsections accordingly provide further detail about data and methods.

\section{The Preferences Database}

Our preferences database is made up of the marginal responses to survey questions relating to domestic policy issues. ${ }^{22}$ These simply record the percentage selecting a 'left' or 'right' option, 'supporting' or 'opposing' specific proposals, 'agreeing' or 'disagreeing' with social, economic and political statements. In each case, respondents are required to take 'sides' or 'positions'. ${ }^{23} \mathrm{We}$ exclude items relating to the foreign affairs policy domain

${ }^{20}$ See James A. Stimson, 'Public Policy Mood: A Personal Narrative', Political Methodologist, 12 (2004), pp. 9-14, at p. 12.

${ }^{21}$ Philip E. Converse, 'Belief Systems in Mass Publics' in David Apter, ed., Ideology and Discontent (New York: Free Press, 1964), pp. 209-64, at p. 209.

${ }^{22}$ Further questions and administrations have been added to the dataset. As of 28 March 2007, it contained 481 questions. This database, together with the estimated preferences for government activity, will be deposited with the Data Archive at the University of Essex.

${ }^{23}$ It has been suggested by some reviewers that the meaning of the 'middle' or supposed 'neutral' response might vary over time and that this might cast some doubt on our coding case. The classic case that such reviewers would seem to have in mind would be the 'keep things as they are' response option that is available to respondents on various tax and spending questions. When a right-wing party is in power, for example, it might be supposed that those who select this option might be revealing conservative attitudes towards change. This might well be the case for some questions and some respondents. It may well be that we could improve our estimates were we able to incorporate such refinements. Identifying the sort of questions for which this might be a problem would however be subjective and identifying the time at which the meaning of the neutral category changes would inject a degree of subjectivity. In any event, our method relies on covariation across a range of items, many of which do not conceivably suffer from 
since prior research has suggested that this represents a highly distinctive dimension that does not correlate with domestic preferences. ${ }^{24} \mathrm{We}$ similarly exclude those questions that refer to a named party or politician. This is simply because the presence of such a cue makes it difficult to untangle preferences (or attitudes towards government activity) from attitude to either party or politician.

After we have imposed all these limitations, the full preferences database contains responses to a total of 441 individual questions related to domestic policy administered a total of 3,151 times. However, for reasons set out below, preferences are estimated using a subset made up of 349 items administered a total number of 2,482 times. The remaining items are used to validate our estimates of the centre.

\section{Changes in Preferences}

Our measure of political preferences is based on observing changes in the distribution of domestic policy preferences over time. Thus, the preferences dataset includes only identical questions asked in at least two separate years. This requirement means dispensing with notable transient issues, such as the 'poll tax' in the late 1980s, because the same questions were, as far as we have been able to establish, never repeated in two separate years. Since even minor variations in question wording, question order, filter style and response categories can produce different responses, we treat such difference as creating different items that cannot be compared over time. ${ }^{25}$ In some cases, very minor variations in question wording were tolerated, especially in the 1950s when data were in short supply. We also generally treated different modes (face-to-face, telephone, selfcompletion questionnaires, etc.) as producing incomparable items.

\section{Coverage}

The measure of the policy preferences that we develop in this article is based on all the domestic policy preference data that were available in the Gallup Political Index, British Election Studies (BES), National Opinion Poll (NOP), International Communications and Marketing (ICM), British Social Attitudes (BSA), British Household Panel Study (BHPS), the European Social Survey, Eurobarometer and YouGov (see Table 1). Our search was both lengthy and intensive and so the collection is - within the limits of what one can know - exhaustive.

The market research industry is still relatively new and subject to change as a result of market conditions and technological change. There are few useful questions in the 1930s, 1940s and even 1950s, when we are reliant on the (now sadly defunct) Gallup Political Index. ${ }^{26}$ Accordingly, we discount our estimates before 1950. Even then, however, the data are thin. We have to rely on a single item in 1950 and 1956 and just four

(F'note continued)

this problem. For the moment - just as with the European preference series - we prefer to maintain a degree of consistency and focus on those responses that clearly take 'sides'.

${ }^{24}$ This excludes very few questions. British pollsters and political scientists have focused largely on domestic affairs in their questionnaires.

${ }^{25}$ Howard Schumann and Stanley Presser, Questions and Answers in Attitude Surveys: Experiments on Question Form, Wording and Context (Thousand Oaks, Calif.: Sage, 1996); Zaller, The Nature and Origins of Mass Opinion.

${ }^{26}$ See George H. Gallup, The Gallup International Public Opinion Polls, Great Britain, 1937-1975 (London: Random House, 1976), 2 volumes. 
TABLE $1 \quad$ Sources Used in This Research

\begin{tabular}{lrrrrr}
\hline \hline & \multicolumn{2}{c}{ Questions } & & \multicolumn{2}{c}{ Administrations } \\
\cline { 2 - 3 } \cline { 5 - 6 } & No. & $\%$ & & $N$ & $\%$ \\
\hline British Election Panel Study & 6 & 1.4 & & 42 & 1.4 \\
British Election Study & 82 & 18.8 & & 289 & 9.6 \\
British Social Attitudes & 165 & 37.8 & & 1085 & 36.0 \\
Eurobarometer & 3 & 0.7 & & 80 & 2.7 \\
Gallup & 128 & 29.4 & & 1056 & 35.0 \\
ICM & 15 & 3.4 & & 158 & 5.2 \\
MORI & 18 & & 2.1 & & 227 \\
NOP & 5 & 1.1 & & 38 & 1.3 \\
World Values Survey & 6 & 1.4 & & 19 & 0.6 \\
YouGov & 8 & 1.8 & & 22 & 0.7 \\
Total & 436 & 100 & 3016 & 100 \\
\hline \hline
\end{tabular}

Note: Based on June 2007 database (excluding foreign policy items)

in $1953 .{ }^{27}$ As we move closer to the present day, however, we face an embarrassment of data riches. The peak in terms of both number of questions $(N=147)$ and separate administrations $(N=161)$ is 1987 , but is still healthy in $2005(N=87$ in terms of both questions and administrations). We have fully-exploited Gallup, the only possible source of data for the 1950s. Nevertheless, the few items that are available in the 1950s relate to issues such as trade unions and nationalization and - as we demonstrate below - these sorts of items tend to load very heavily on our extracted preference series. Preferences have been so well documented since the 1970s, moreover, that new bits of data are unlikely to make much difference.

As a check on the impact of small numbers of items first and foremost, we have estimated standard errors of our annual estimates. We can estimate a biennial rather than annual time series to see if the main patterns are altered when twice as many items contribute to each estimate. That exercise produces no notable changes.

\section{Indexing Preferences}

In order to estimate preferences for government activity, responses were simply coded as either 'left' or 'right' and 'neutral'. The latter were discarded from the analysis and an index of preferences calculated:

$$
\text { Index of Preferences }=\frac{\sum_{i=1}^{N}(\text { Left Preferences })}{\sum_{i=1}^{\mathrm{N}}(\text { Left and Right Preferences })} .
$$

\footnotetext{
${ }^{27}$ It should be noted, however, that we are relying here on important questions about trade unions and nationalization, probably the key issues defining the political battleground of the time. These sorts of items tend to load very heavily on our estimated preference series, something that boosts our confidence in our measure for these earlier years.
} 
In general, it is a simple task to decide on the directional thrust of the responses. That is, it was easy to code responses as 'left' or 'right'. This is hardly surprising. British politicians have 'framed' many issues in terms of 'left' and 'right' and survey designers have taken note, thus allowing easy coding of responses. ${ }^{28}$ Moreover, even if we made a mistake in coding, the extraction algorithm would still be able to use the information as long as we had been consistent.

The only major coding difficulty relates to Europe, which has been the subject of data collection efforts since British entry was first floated in 1961. This policy domain arguably lies somewhere between a 'domestic' and 'foreign affairs' issue, though as integration has increased 'Europe' has had a greater impact on domestic policy. The issue has also created divisions on both the left and right for the best part of forty years. The bulk of 'the right' tended to support membership of the then European Economic Community and the formation of the single market under the European Community in the 1980s. ${ }^{29}$ As the European Union challenged national sovereignty by moving towards monetary union and developing a 'social dimension', however, many on the right became sceptical about the European project. After Mrs Thatcher's removal from office in November 1990, much of the Conservative party drifted to a far more sceptical position and some joined explicitly antiEuropean parties such as the Referendum Party and the United Kingdom Independence Party. 'The left', by contrast, were hopelessly divided on Europe until the late $1980 \mathrm{~s}^{30}$ The left tended to oppose membership of the 'capitalist club', while moderate social democrats tended to enthusiastically support membership. ${ }^{31}$ It was not until the emergence of a 'social dimension' in the early 1990s that being pro-Europe became a 'left' position.

Given the detailed knowledge of the European issue, it is tempting to impose the assumption that the 'polarities' reversed at some specific date. But pinpointing the exact date would be hazardous and require a fine judgement call. Rather than do this, we (tentatively) code pro-European responses as left and anti-European responses as right. We do not, however, include European items in our estimate of preferences for government activity. This allows us to observe, rather than assume, the relationship between left-right and European preferences.

\section{Self-Reported Left-Right Positions}

The most obvious way of estimating voters' left-right positions is to ask voters to locate themselves on a general left-right scale. At the individual level at least, this method is problematic. Responses to such questions do not express clear preferences over outcomes. They may be empirically related to outcomes but - on the face of it at least - refer simply to the labels that people may attach to themselves. While the small group of politically sophisticated voters may use these labels correctly, the great mass of unsophisticated citizens may not know how to use the labels or know what they mean. ${ }^{32}$ Indeed, it is all

\footnotetext{
${ }^{28}$ In some cases, the inclusion of the phrase 'the government' causes problems because it is not always clear whether the question will be interpreted as meaning the present government or government in general. We have included such questions in those cases where it seems to refer to government in general.

${ }^{29}$ Hugo Young, This Blessed Plot (London: Macmillan, 1998); Anthony Forster, Euroscepticism in Contemporary British Politics (London: Routledge, 2002).

30 Tom Nairn, The Left Against Europe? (London: Penguin, 1973).

31 This represents a heroic generalization. For exceptions, see Young, This Blessed Plot, chap. 5.

32 See Janet M. Box-Steffensmeier, Kathleen Knight and Lee Sigelman, 'The Interplay between MacroPartisanship and Macro-Ideology: A Time Series Study', Journal of Politics, 60 (1998), 1031-49; Janet M.
} 
too likely that many may guess or infer their left-right position from their understandings of where their parties are located. ${ }^{33}$

Still, it could be argued that, at the aggregate level, these things wash out and that ideological self-location should track real preferences. Variations in reported self-location may, therefore, approximate shifts in preferences. In order to produce a somewhat cleaner set of estimates that is less vulnerable to challenge, however, we exclude these measures from the preferences for government activity series, and - just as with European preferences - we use self-reported left-right positions only to validate these estimates.

In the event, neither of these decisions - to omit European preferences and left-right self-locations - have significant empirical consequences. Indeed, they hardly affect our estimates of the political centre at all.

\section{ESTIMATING THE MOVING CENTRE}

Our goal is to locate that - hitherto - mythical median British voter and track him or her over time as preferences change to reflect circumstances. Our device for doing so is (1) to observe raw preferences as expressed in aggregate responses to survey probes about preferred policy choices and (2) to solve for their moving central tendency over time. Policy preferences vary across people and over time. Our interest is only the latter. Thus, at the outset, we score policy preferences as a net disposition across the whole of British society, typically as a percentage choosing the left option (or options) in a question that offers both left and right choices. ${ }^{34}$ Then we observe how that percentage varies over time.

The issue then becomes how to extract the central tendency from a very large number of observed preference series. This is of the class of problems to which principal components analysis - or more loosely, factor analysis - is the solution. Principal components analysis itself is not workable for data of this sort because most of the possible cases - the answers to a potential survey question in year $t$ - are missing. To impute values for those missing cases, which considerably outnumber observed cases, would create a dangerous dependency on the assumptions underlying the imputation. In some cases, those assumptions are relatively benign; for example, a missing year might be well imputed as an average of the years before and after. In many cases, the assumptions are heroic. Imputation might be required to create values for a question series, for example, before it was ever posed the first time and after it was posed the last time.

To deal with the actual structure of the public opinion data we have, we adopt the Dyad Ratios algorithm. ${ }^{35}$ We describe the algorithm briefly here for readers who are not familiar with it. We begin with the data.

(F'note continued)

Box-Steffensmeier and Suzanna De Boef, 'Macropartisanship and Macroideology in the Sophisticated Electorate', Journal of Politics, 63 (2001), 232-48. This paper suggests that 'for the politically sophisticated group, there was a connection between macropartisanship and macroideology', p. 245.

${ }^{33}$ Elinor Scarbrough, Political Ideology and Voting Behaviour: An Exploratory Study (Oxford: Clarendon Press, 1984).

34 One might reasonably ask how we can observe the 'median' when we have discarded the distribution of individual responses. The answer is that we cannot. What we actually do is solve for the central tendency of preferences and then interpret that result as the preferences of the median voter.

${ }^{35}$ The algorithm is developed in Stimson, Public Opinion in America. It has been used in various studies including Jeffrey E. Cohen, 'The Polls: Public Favourability toward the First Lady', Presidential Studies Quarterly, 30 (2000), 575-85; Virginia A. Chanley, Thomas J. Rudolph and Wendy M. Rahn, 'The Origins 
What we have for data are numerous series of a single survey item posed to comparable national samples at various times. We wish to estimate the centre for $N$ years (here $N=56$ ) from input data series each of length $k$, where $k$ is always less than $N$. We wish to avoid the untenable assumptions (1) that any two different questions are or are not comparable, and (2) that anything can be known about a series in a year that it is not posed.

What that leaves as bedrock knowledge is the assertion that ratios of the responses to the same question at different times are useful information about opinion change. ${ }^{36}$ Each of the two possible cases forms a dyad, and hence the name, dyad ratios algorithm. More formally, assuming that each indicator series is scored to represent left opinion - i.e., larger numbers represent an opinion further to the left - we are asserting that for:

$$
R_{i j}=\frac{x_{t+i}}{x_{t+j}}
$$

$R_{i j}$ represents a reasonable estimate of how left opinion was in years $t+i$ and $t+j$. This is not to say that $R$ is a 'best' or even 'good' estimate of the concept. For a 'best' estimate will be efficient in the sense that it is based upon all the information at hand and not merely one arbitrary choice. For each series of length $k$, we have multiple ratio estimates. These tell us plenty about the years for which the series is measured and nothing about the years when it is not.

Note the gain from switching from raw measures (percentage left) to ratios. In the case of raw measures, a missing case has an unknown expected value. ${ }^{37}$ For a ratio, in contrast, the expected value of the ratio of any two cases is 1.0. That will justify combining estimates derived from different subsets of indicators. No matter what question wording is employed, two valid indicators of the same concept will have the same expected values for ratios.

For multiple series, the question becomes how to combine a very large number of possible ratios into a single estimate. If - a very big if - a single year $i$ were available for all series, then it could serve as a universal base that would give meaning to all the ratios. This is the logic of economic indicators in which a base year is given an arbitrary value, often 100, which then propagates meaningful values to all other years. But this condition is not satisfied by our data. There is no one year where every possible survey question about preferences is posed.

That forces us to choose a next best solution, recursive estimation. Since there is no universal base year for calculation, we form recursive estimates of each year from all the available data pertaining to that year. Thus, we cannot know that Year 2, for example, is 100 .

(F'note continued)

and Consequences of Public Trust in Government: A Time Series Analysis', Public Opinion Quarterly, 64 (2000), 239-56; Erikson et al., The Macro Polity, chaps 6 and 7; Paul M. Kellstedt, The Mass Media and the Dynamics of American Racial Attitudes (Cambridge: Cambridge University Press, 2003); Erik Voeten and Paul R. Brewer, 'Public Opinion, the War in Iraq, and Presidential Accountability', Journal of Conflict Resolution, 50 (2006), 809-30; Frank R. Baumgartner, Suzanna L. De Boef and Amber E. Boydstun, The Decline of the Death Penalty and the Discovery of Innocence (Cambridge: Cambridge University Press, 2008).

36 That depends, as always, on the degree to which each series is a valid indicator of the concept in question, here left-right public opinion. This is a matter for which the empirical results will be informative.

37 One might think that the problem is easily solved, that the mean of a series can serve as an expected value. But this is an infinite regress problem. Without either the full series or a random sample of it, we have no valid estimate of that mean. 
But we can know that Year 2 is some computable ratio of Year 1, based on all the data which are available for times 1 and 2. Thus, we let Year 1 be arbitrary, say 100, and then calculate an average Year $1 /$ Year 2 ratio from all the data that connect the two cases to form a best estimate of Year 2 in absolute terms. Then this value can be similarly applied to years $3,4, \ldots k$ in the same fashion. This is recursive estimation.

We now have in hand multiple - often multiple hundred - estimates of the same quantity, the absolute leftness of preferences in a particular year, $P_{t}$. The large number of overlapping estimates derives from the fact that each series provides $k-1$ separate estimates of each year where it is available and then there are hundreds of series. A natural first intuition about combining these separate estimates, $x_{t k}$, is to find their central tendency (denoted $P_{t}$ for preferences at time $t$ ):

$$
P_{t}=\frac{\sum_{k=1}^{N} x_{t k}}{N}
$$

But we can do better than that. We know that the items in the analysis are not equally valid indicators of the concept, left-right. Therefore, we can estimate those validities squared correlations with the latent dimension - and use those estimates to weight items in proportion to their indicator validity, $h_{i}^{2}$ :

$$
P_{t}=\frac{\sum_{k=1}^{N} h_{i}^{2} x_{t k}}{h^{2} N}
$$

where $h_{i}^{2}$ in the numerator is the communality estimate (i.e., validity) of item $i$ and $h^{2}$ in the denominator is the average communality across all items.

Recursive estimation can be done forward in time, as described above, or equally well backward. In that case, year $T$ is set to 100 and all earlier years are estimated empirically. The two approaches weight earlier and later cases differently, so that the resulting estimates are not the same. That permits reliability estimation (from the correlations of the two). A final estimate averages the two equally valid approaches.

In principal components, there are three common approaches to the thorny issue of estimating the common variances of individual items. One is to assume (falsely in all actual cases) that each is perfectly valid, in which case 1.0 is the communality estimate placed on the major diagonal of the correlation matrix. A second forms the communality estimate from the $R^{2}$ of each indicator regressed on all the others. And a third, usually preferred, approach is iterative. Each iteration begins with assumed communalities from which improved ones can be estimated. Then the improved estimates become assumed values for the next iteration. And so on until convergence is achieved when the difference between the assumed and the estimated is arbitrarily small. The dyad ratios algorithm implements the third, iterative, approach.

Since the recourse to ratios causes the original metric to be lost, it is reintroduced to ease interpretation by a standardization of the latent scale in terms of the validityweighted means and standard deviations of the input items. Since the individual items are scored as per cent left over per cent left plus per cent right, the resulting scale has the same interpretation. Fifty is a neutral point where left and right alternatives are chosen with equal frequency. Values above 50 indicate a net preference for the left and below 50 a net preference for the right. 
The outcome data, as in principal components, tell us for each item how much of its variance is shared with the latent estimated dimension, i.e., its validity, and how heavily it loads on each possible dimension. The latter we employ in the manner of all dimensional analyses to learn what the latent dimensions mean. ${ }^{38}$

\section{THE EXTRACTED ESTIMATES}

Having laid bare the technology, we turn our attention to the estimates. Figure 1 displays our estimate of the public preferences series from 1950 through to 2005. This represents our best estimate of the 'centre' in the post-war period. The series starts off high (left) in 1950s and then generally drifts down (right). Pleasingly, this overall pattern seems to agree with several widely praised historical commentaries. In his A History of Modern Britain, for example, Andrew Marr claims that the Second World War 'changed Britain's political climate and our attitude to government' and that by 1945 the mood was for 'big government, digging deep into people's lives to improve them. ${ }^{39}$ He then (rightly) claims that 'by the time the last big struggle to nationalise an industry was underway, the steel debates of 1948-49, the public mood was already turning' and that 'the government felt a change in the weather'. ${ }^{40}$ Preferences generally continued to drift right until 1979, the very year that Mrs Thatcher came to power.

Our finding here ties in well with the research of Ivor Crewe and his colleagues, who noted a decline in support for the 'collectivist trinity' of public ownership, trade unions and the welfare state from the 1960s through to the 1979 general election. ${ }^{41}$ It also sheds some light on why James Callaghan, then Labour leader and prime minister, confided to his policy adviser during the 1979 general election campaign: 'You know there are times, perhaps once every thirty years, when there is a sea-change in politics. It then does not matter what you say or what you do. I suspect there is now such a sea change - and it is for Mrs Thatcher. ${ }^{42}$

Callaghan was clearly correct to say that there had been a 'sea change'. As our evidence makes clear, however, the change in preferences long pre-dated the specific circumstances of the 1979 general election and the so-called 'Winter of Discontent' of 1978/79 that immediately preceded it.

From 1979 onwards, the series tracks remorselessly to the left, peaking in 1997, the year of New Labour's triumph. This finding supports the findings of Crewe, Heath et al. and Crewe and Searing, who find that the electorate generally moved away from 'Thatcherite'

\footnotetext{
${ }^{38}$ The extraction algorithm can also be used to estimate a second dimension. This accounts for far less of the variation in the longitudinal variation and is more difficult to interpret. It does not, however, appear to represent the sort of liberal-authoritarian dimension or 'tough v. tender' dimension of the sort anticipated in the textbooks. We explore the issue of dimensionality further in John Bartle, Sebastian Dellepiane and James A. Stimson, 'The Dimensionality of British Political Preferences, 1950-2005' (paper presented at the 5th ECPR General Conference, Potsdam, 2009 - available from the authors).

39 Andrew Marr, A History of Modern Britain (Basingstoke, Hants.: Macmillan, 2007), p. xi, p. 28 and p. 70 .

${ }^{40}$ Marr, A History of Modern Britain, p. 70.

${ }^{41}$ Ivor Crewe, Bo Särlvik, B. and James Alt, 'Partisan Dealignment in Britain ,1964-1974', British Journal of Political Science, 7 (1977), 129-90; Ivor Crewe, 'The Labour Party and the Electorate', in Dennis Kavanagh, ed., The Politics of the Labour Party (London: George Allen \& Unwin, 1982), pp. $9-49$.

${ }^{42}$ Bernard Donoghue, Prime Minister: The Conduct of Policy under Wilson and Callaghan (London: Jonathan Cape, 1987), p. 191.
} 


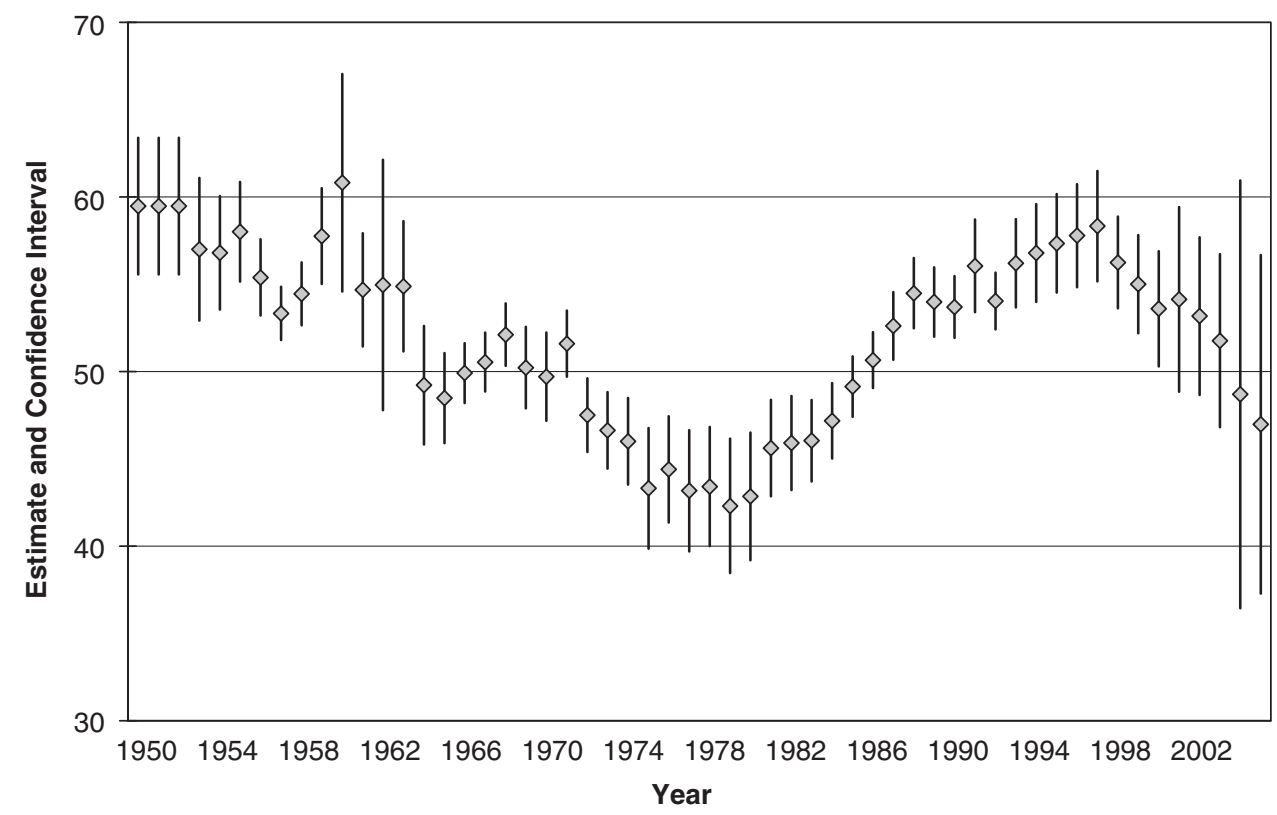

Fig. 1. Estimates of Left-Right Preferences with Confidence Intervals, 1950-2005

positions during her period as prime minister. ${ }^{43}$ The series then drifts right again under New Labour, until by 2005 it was roughly where it had been in 1983, the year when Mrs Thatcher won a landslide victory.

The figure shows our best point estimate of left-right policy preferences along with an estimated confidence interval for each annual estimate, which is the point estimate plus or minus two standard errors. ${ }^{44}$ The standard errors reflect how pivotal the various data points are. Variations in particularly important years have relatively large consequences, whereas in most years they do not.

${ }^{43}$ Ivor Crewe, 'Has the Electorate Become Thatcherite?' in Robert Skidelsky, ed., Thatcherism (London: Chatto \& Windus, 1988), pp. 25-49; Ivor Crewe, 'Values: The Crusade that Failed', in Dennis Kavanagh and Anthony Seldon, eds, The Thatcher Effect (Oxford: Oxford University Press, 1989), pp. 239-50; Ivor Crewe and Donald D. Searing, 'Ideological Change in the British Conservative Party', American Political Science Review, 82 (1988), 361-84; Anthony Heath, Roger Jowell and John Curtice, How Britain Votes (Oxford: Oxford University Press, 1985); Anthony Heath, John Curtice, Roger Jowell, Geoffrey Evans, Julia Field and Sharon Witherspoon, Understanding Political Change: The British Voter 1964-1987 (Oxford: Pergamon Press, 1991).

${ }^{44}$ The dyad ratios algorithm has no analytic solution for standard errors of the annual estimates. We proceed instead by bootstrapping. We first introduce variation by re-sampling our raw data. Instead of the fixed percentage reported by a survey organization, $\rho$, we take a draw for each (non-missing) item and year from a distribution which is normal with mean $\rho$ and a standard deviation given by the sampling error of $\rho, \sigma=\sqrt{ }[\rho(100-\rho) / N]$. This allows us to repeat the estimation of the latent series as many times as we wish, each sampling slightly different data and returning different results. The standard deviations for each period of all those independent replications, 1,000 in the case at hand, become the standard error estimates that we report. We have not yet been able to establish why the errors are larger towards the end of the series. 
On the face of it, preferences appear to be divided into three distinct periods: moving to the right from the 1950s through to 1979, to the left between 1979 and 1997 and back to the right since 1997. From what we know of British political history, and informed by Wlezien's thermostatic model, it is tempting to link this pattern to variations in the size of the state, which generally expanded in the first period, contracted in the second and then rolled forward again in the third. ${ }^{45}$ It is likely, however, that more directly economic factors also were at play. In the next sections, we examine the validity of the extracted measure by considering which variables are most heavily associated with the estimated series and also its relationship with both left-right self-locations and attitudes towards Europe.

Dimensional analysis. While the picture provided by Figure 1 is generally quite plausible, we need to establish whether the estimates are indeed capturing left-right preferences and movements in the centre. One obvious way of establishing whether our estimated series is indeed capturing preferences for government activity is to examine the loadings for those individual items that make up the scale. Given that the series is based on 349 items asked in 2,482 separate administrations, it would be too messy to display all the loadings. Some items are, moreover, included only twice. While such items would have factor loadings of 1.0 (or -1.0 ), they would provide a misleading indicator of content. Table 2, therefore, simply reports the highest loadings for only those items that were included in the database on at least ten occasions and load more than 0.50 on the public preferences dimension. ${ }^{46}$

The first thing to note about Table 2 is that the estimated preference series explains over 43 per cent of the variation in these assorted series. Given the very large number of items, this seems - to us at any rate - quite impressive. More importantly, however, even a brief examination of Table 2 is enough to demonstrate that it is dominated by items relating to trade unions, to the power of business, to taxing and spending and to equality, while the welfare estate, the monarchy and nuclear power also load highly on the scale.

This provides some reassurance that the series is capturing a large part of the battle between Labour and the Conservatives about the extent of state activity. Indeed, we would have been surprised if we had found anything else. It should also be noted, however, that some items that are only remotely related to government activity (such as nuclear power, post-materialism and abortion) also load heavily on the extracted dimension. Put simply, when overall preferences move, so do things that one might think were totally unrelated. This suggests that the extracted dimension is actually picking up something rather more general than preferences for government activity.

Relationship with self-reported left-right positions. The dimensional analysis contained in Table 2 suggests that the estimate of public preferences reflects a general left-right dimension. But a sceptic might well demand additional confirmation. In this sub-section, we assess the relationship between the series and other measures of left-right position. We are fortunate that the Eurobarometer has asked respondents to report their own left-right positions every year since $1973 .{ }^{47}$ In addition, Gallup and the BES also asked similar questions, somewhat less regularly, in this same period. These series can be combined to generate a single left-right

\footnotetext{
45 Wlezien, 'The Public as Thermostat'.

46 The full factor loadings for the 349 items are available from the authors on request.

47 The earlier British Election Studies also asked about the reported left-right position, but the filter question generated so much missing data that the resulting marginals were not included in our database.
} 
TA B LE 2 Dimensional Analysis of Preferences Series, 1950-2005

\begin{tabular}{llcc}
\hline \hline Question & House & $N$ & Loading \\
\hline Trade-union power & Gallup & 22 & 0.96 \\
Trade-union power & MORI & 15 & 0.98 \\
Nuclear energy & Gallup & 10 & 0.93 \\
Tax and spending & Gallup & 20 & 0.93 \\
Trade unions good & Gallup & 40 & 0.89 \\
Trade unions extreme & MORI & 14 & 0.88 \\
Trade-union closed shop & Gallup & 11 & 0.83 \\
People don't deserve benefits & Gallup & 15 & 0.83 \\
Tax and spending & BSA & 21 & 0.81 \\
Ordinary people get fair share & BSA & 16 & 0.79 \\
Post materialism & Eurobarometer & 22 & 0.79 \\
One law for the rich, another for the poor & BSA & 19 & 0.77 \\
Welfare benefits & BSA & 15 & 0.75 \\
Equal opportunities for women & BES/BSA & 10 & 0.74 \\
Better off without monarchy & MORI & 12 & 0.73 \\
Class struggle & BES & 14 & 0.73 \\
Trade unions essential & MORI & 15 & 0.73 \\
Pension spending & Gallup & 20 & 0.72 \\
Unemployed could get jobs & BSA & 15 & 0.72 \\
Business too powerful & BES & 10 & 0.69 \\
Abortion if poor & BSA & 11 & 0.67 \\
Redistribution of wealth & BSA & 19 & 0.66 \\
Car taxes higher & BSA & 14 & 0.64 \\
Keep monarch & BSA & 10 & 0.59 \\
Trade-union power & BSA & 18 & 0.58 \\
Unemployed fiddle dole & BSA & 15 & 0.55 \\
Limit availability of NHS & BSA & 17 & 0.54 \\
Welfare spending & BSA & 15 & 0.52 \\
Reduce income differences & BSA & 10 & 0.52 \\
Abortion if don't want child & BSA & 10 & 0.51 \\
Obey wrong laws & BSA & 15 & 0.51 \\
Business benefits owners & BSA & 17 & 0.50 \\
\hline
\end{tabular}

Note: This table contains only those items that are entered into the database in ten separate administrations and have a loading above 0.5 .

self-placement series using the same extraction algorithm used for the preference series, and we can then examine its relationship with the extracted series (see Figure 2).

Figure 2 also displays the preferences series and self-reported left-right positions from 1973 onwards. ${ }^{48}$ This figure shows that the two series track each other quite well, though reported positions continued to increase (move leftwards) between 1997 and 2002, when policy preferences were decreasing (moving right). This suggests that self-reported positions might be a lagging indicator. ${ }^{49}$ It may simply be that voters who have voted for a 'left' party in 1997

\footnotetext{
48 The latter, it should be remembered, is not included in the former.

${ }^{49}$ Some indication that this is the case is provided by a simple regression of current preferences and current self-reported left-right position on the same indicators lagged one year. In the model of selfreported positions, lagged self-reported left-right positions and lagged policy preferences are correctly signed and statistically significant. In the model of current preferences, both lagged preferences and lagged
} 




Fig. 2. Relationship between preferences for government activity, Europe and left-right self locations

and 2001 assume that they must be left too or that social desirability is at play. In any case, the product moment correlation for the two series is an impressive $0.66(N=33, p<0.000)$. Movements of reported left-right positions are associated with 'real' preferences.

It should be finally noted that the correlation between our measure of preferences for government activity without reported left-right positions and the same measure with selfreported positions over the thirty-two years between 1973 and 2005 is a mighty 0.99 . It seems that the decision to exclude self-reported left-right positions is more firmly rooted in intuitions about the meaning of 'preferences' than in the data. This finding suggests that where preference data are in short supply (in studies of preferences in other countries, for example), changes in self-reported positions might be useful proxies for changes in aggregate preferences.

Relationship with European Preferences. It is unclear whether positions on the European issue are essentially 'domestic' or 'international' in nature and thus their relationship with 'left' and 'right' is, furthermore, uncertain. For these reasons, we excluded those items that referred to Europe from the dataset we used to generate our estimates of preferences relating to government activity. Instead, we set these data aside and employed the dyad ratio algorithm to produce a pure measure of latent attitudes towards Europe.

Figure 2 displays preferences relating to Europe from 1961 onwards. The association between the two series in this case does not appear to be quite as good as that for selfreported left-right positions. Nevertheless, the two series generally fit quite well. The 1970s, on the one hand, witnessed a drift to the right in terms of both preferences and a drift towards Euroscepticism. The 1980s, on the other hand, witnessed a drift to the left

(F'note continued)

self-reported left-right positions are significant, but the latter is incorrectly signed, suggesting that if they were rising one year ago, preferences fall. Self-reported left-right positions: Constant $=-3.23(2.95)^{*}$, Lagged preferences $=0.82(0.08)$, Lagged self-reported positions $=0.26(0.06)$, Adjusted $R^{2}=0.93$, $N=31$; Public preferences: Constant $=3.73^{*}(2.47)$, Lagged preferences $=1.09$ (0.07), Lagged selfreported positions $=-0.16(0.05)$, Adjusted $R^{2}=0.93, N=31$ (*Not significant at $p<0.05$, two-tailed). 
and increasing support for Europe that reversed itself from around 1991 onwards. The early to mid-1990s combined a slight shift to the left with increased Euroscepticism. From 1997 onwards, the two series marched in step: towards the right and Eurosceptical poles. Yet again, the real test is the correlation between the two series. The product moment correlation for the two is $0.54(N=45, p<0.000)$. Although it has been suggested that Europe represents a new dimension of British politics, quite separate from the 'old' politics of left and right, the data suggest that there is an association between the two. ${ }^{50}$

Figure 2 suggests that our exclusion of reported left-right positions and the European items is more firmly rooted in theoretical considerations than in the data. If we had included the European data in our indicator of preferences, it would have made little difference. The correlation between the two series with and without European items is 0.98. The decision to exclude the European data - like left-right self-reported positions makes virtually no empirical difference.

Naming the series. We have noted that items relating to taxation, spending and state activity loom large in the preferences series. Since other issues traditionally associated with left and right, such as abortion, nuclear power and post-materialism, also load heavily on the series and since it correlates quite highly with self-reported left-right positions, there seem to be grounds for believing that we have produced a plausible general measure of left-right positions. Indeed, perhaps we should not find this surprising. Theories of 'issue evolution' produce the clear expectation that many - even most - issues will eventually be incorporated in the left-right dimension as parties take positions and voters sort themselves into the right parties. ${ }^{51}$ While we are reasonably confident that we have a measure of general left-right positions, we leave it to the reader to decide whether our findings support that proposition.

\section{WHAT MOVES PREFERENCES?}

We have shown that preferences move left and right over time. Here, we take on the challenge of explaining why. Most of the movements are small. Indeed, the average annual change, ignoring the sign of the change, is a mere 1.5 points over the full fifty-six years examined here. The largest annual changes occur in 1960-61 (-6.1) and 1964-65 $(-5.7)$, but this may owe a good deal to the thinness of the data at that period (see Figure 1). Beyond this, there is little to suggest that individual events may have affected preferences a great deal. Indeed, such a pattern of small but cumulative change strongly hints at the influence of systemic, macro-level forces.

\section{Theory}

To get beneath the longitudinal flow of issue preferences, it is useful to think about the cross-sectional distribution of preferences. Assume that Britain faces a continuing choice of more or fewer government activities and services and the taxes to pay for them. ${ }^{52}$

50 Paul Webb, The Modern British Party System (London: Sage, 2000), chap. 3; Geoffrey Evans, 'Europe: A New Cleavage?' in Geoffrey Evans and Pippa Norris, eds, Critical Elections: British Parties and Voters in Long-term Perspective (London: Sage, 1999), pp. 207-22.

51 See Edward G. Carmines and James A. Stimson, Issue Evolution: Race and the Transformation of American Politics (Princeton, N.J.: Princeton University Press, 1989); Stimson, Tides of Consent, chap. 3.

52 See Evan Davies, Public Spending (London: Penguin, 1998). 
The extremes of this choice, anarchy at one end and total government at the other, are never attained. Thus, we may think of arraying all citizens into degrees of preferring more or less government and dividing this space of preferences into three groupings, those who want more government than Labour provides, those who want less than the Conservatives provide, and those somewhere in between. ${ }^{53}$

Now, in this hypothetical space, it will be clear that the groups of the extreme left (who want more government than Labour provides) and those of the extreme right (who similarly want less than they ever get from Conservatives) will never be satisfied. Thus, their views should never change. Wanting more (or less) and never getting it implies that they should always continue to want more (or less). That leaves those in between the parties as the only citizens who have a motive to change preferences over time. As control of government alternates between the party of the left and the party of the right, they will see themselves forced to change relative preferences in order to stay constant in absolute terms. ${ }^{54}$

Imagine a citizen in between but relatively close to the Conservatives in preferences. While Conservatives hold power, that citizen will prefer (slightly) more government than he or she gets. When Labour takes control, it will increase the mix of services and taxes and our citizen will soon find that the government is doing more than he or she wished and will need to switch relative preferences to less.

In this story of absolute and relative preferences for the size of government, it is clear that for a rational citizenry the dynamic element is entirely in the middle. Therefore, as we aggregate these preferences and observe them over time, we should observe (1) that all the action is in the centre, and (2) that the dynamics will produce the thermostatic response that Christopher Wlezien hypothesizes. ${ }^{55}$ If we can envision the sum total of public policy on a dimension of more or less government - easy in theory and a little challenging for empirical measurement - then our basic expectation is that citizens will respond to government over time by demanding less of the direction of policy that they are currently receiving.

On to this expectation, which is entirely endogenous to the choices that governments make, we will observe also some factors which are relatively exogenous. Chief among these will be movements in the macro-economy which are capable of altering (absolute) preferences for the level of government. A government experiencing high levels of unemployment, for example, will lead some citizens to prefer a higher level of government activity as a Keynesian response. Thus, independently of our hypothesized timeless basic level of preferred government, some citizens will shift leftwards for a period of time when government is seen as not doing enough to cope with the economic difficulty of unemployment. Inflation provides the reverse case. To the degree that it may be attributed to excess stimulation by government, some citizens might for a period of time rationally prefer less government as a policy response.

From this simple story, we may now formulate empirical expectations of how our observed relative preferences for more or less government will shift over time. Most basically, we expect such preferences to run counter to the dominant flow of policy making, moving left in response to policy of the right and moving right in response to

\footnotetext{
53 Since Britain has three major parties, not two, we see the Liberal Democrats complicating the picture by sometimes falling between the other two parties and sometimes emphasizing different issues. We ignore the complication.

${ }^{54}$ See Stanley Feldman and John R. Zaller, 'The Political Culture of Ambivalence: Ideological Responses to the Welfare State', American Journal of Political Science, 36 (1992), 268-307.

${ }^{55}$ Wlezien, 'The Public as Thermostat', pp. 985-9.
} 
policy of the left. We will take two empirical approaches to this issue. We first expect the direction of preferences to shift in response to party control - which assumes implicitly that parties do what they are supposed to do, Conservatives reducing government and Labour increasing it, which is not always true. Then we will assess our macro-level explanations starting first with economic factors, which predict that unemployment will increase support for government activity and inflation will reduce it. And finally, we will introduce empirical indicators of our size of government concept, average tax levels and government expenditure as a proportion of gross domestic product (GDP).

\section{Analysis}

Parties may be ignorant of public opinion, and they may in any case pursue their ideological goals without constant reference to it. In these circumstances, we might expect parties of the left to provide too much government activity and governments of the right too little. In line with Christopher Wlezien's thermostat model, we expect that preferences should move left under the Conservatives and right under Labour.

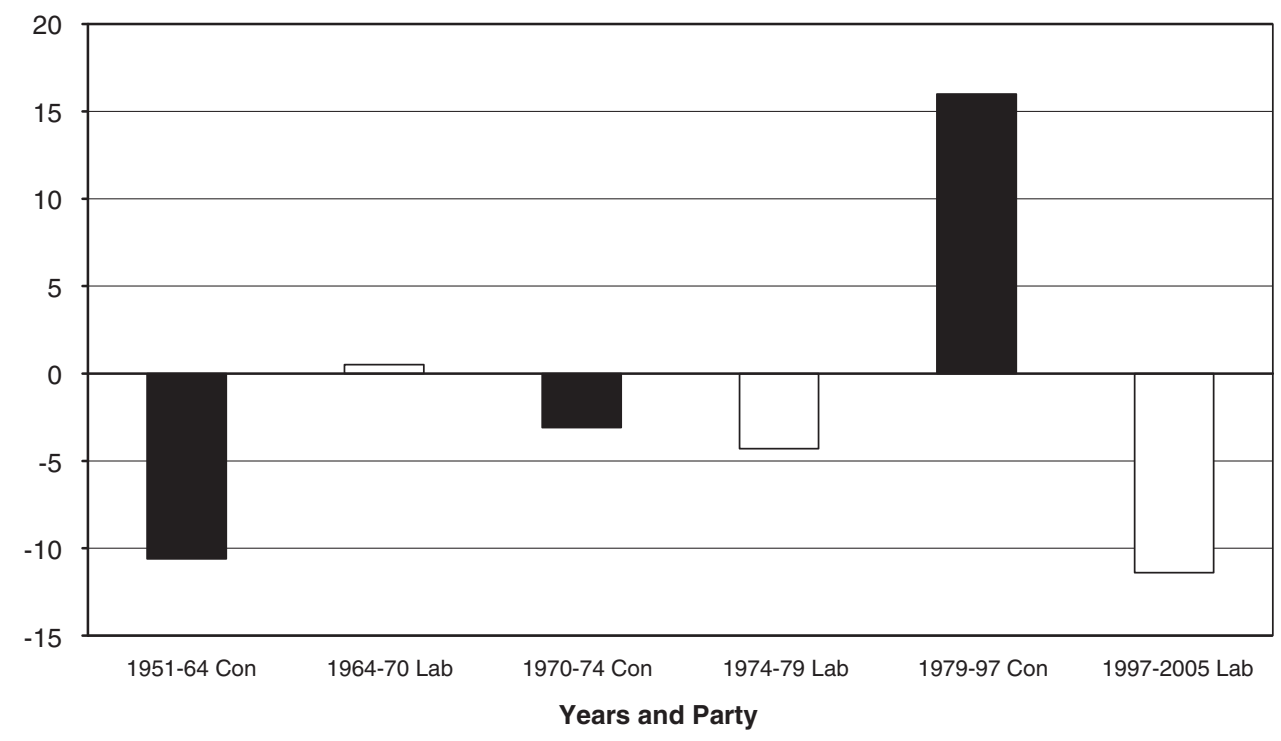

Fig. 3. Changes in preferences for each government, 1951-2005

Figure 3 summarizes the changes in preferences under Conservative and Labour governments. This provides some qualified support for the thermostat idea. ${ }^{56}$ The preference series certainly moved right under Labour governments in 1974-79 and in 1997-2005 (see Figure 3). It also moved left under the eighteen years of Conservative rule from 1979 to 1997. Curiously, however, the pattern of changes under the three governments between 1950 and 1974 are in exactly the wrong direction. Preferences move right under the Conservatives in two periods, 1951-64 and 1970-74, and marginally left under Labour in 1964-70. Therefore, we need to take a more systematic look at the phenomenon. For that, we turn to a regression analysis predicting movements of our estimated centre.

${ }^{56}$ Wlezien, 'The Public as Thermostat'. 
We begin our analyses with the simple question of the effect of party control. Although parties can and do vary in the degree to which they pursue distinctive policies, a voter could do reasonably well using the heuristic that Conservatives will tend to reduce the size of government and Labour will tend to increase it. Thus, the simple fact of party control might summarize the idea that preferences move contrary to the dominant direction of policy making.

The most basic test of this idea is simply to ask whether the direction of change in preferences responds to the party of government. ${ }^{57}$ We expect the public to move left under Conservative rule and right under Labour. We can tap this with a regression of change of preferences on a party dummy variable $(0=$ Conservative, $1=$ Labour $)$. An initial result is displayed in column 1 of Table 3 .

TA B LE 3 Effects of Party Control of Government on Changes in Preferences

\begin{tabular}{lcc}
\hline \hline Variable & 1. All years & 2. 1974-2005 \\
\hline Intercept (Conservative) & 0.06 & $0.81^{*}$ \\
Incumbent Party Dummy (Labour $=1)$ & $(0.33)$ & $(0.28)$ \\
$N$ & -0.79 & $-1.97^{*}$ \\
$R^{2}$ & $(0.55)$ & $(0.43)$ \\
& 55 & 32 \\
\hline \hline
\end{tabular}

$* p<0.01$.

What we see is a result that is correctly signed but not conventionally significant $(p<0.08)$. The reference category (Conservative) shows changes towards the left (positive sign), albeit very slight, while the Labour category predicts movements towards the right (negative sign). Given what we have seen in Figure 3, this comes as no surprise. During the era of 'consensus politics', when Conservative and Labour broadly agreed on the need for a mixed economy and government activity, governments of both parties did things more usually associated with the other party. The governments of the 1950s and early 1960s produced responses sometimes opposite to those predicted by their ideology. The Conservatives expanded state activity in the immediate post-war period and co-operated with the trade unions between 1951 and $1964{ }^{58}$ The 1970-74 Heath government initially tried to reduce government activity and then massively expanded it in a famous policy 'U-turn'. ${ }^{59}$ Equally, the Labour government between 1964 and 1970 had to cut its ambitious spending plans, abandon its 'national plan' and tried to introduce legal restraints on the trade unions. ${ }^{60}$

In the second column of Table 3, we restrict analysis to the period beginning in 1974 and pose the same question. For the last thirty-two year period, the expected effect emerges and quite strongly. ${ }^{61}$ The coefficients indicate that every year of Conservative government drives preferences about 0.80 to the left and every year of Labour government pushes

57 A Dickey-Fuller test indicates the presence of a unit root in the preferences series. So, henceforth, we will work with first differences in the series or analogously employ an error correction formulation which is appropriate for integrated time series.

58 Kavanagh, Thatcherism and British Politics, chaps 3-4.

59 Jenkins, Mrs Thatcher's Revolution, chap. 1.

60 Clive Ponting, Breach of Promise (London: Hamish Hamilton, 1989).

61 We have also considered analysis of the longer period, 1965-2005. That produces a compromise result where the effects are also highly significant, but less sharp than the shorter period of Table 3 . 
preferences even more strongly to the right $(-1.97)$. But our theory is more general. The party dummy variable approach is a crude indicator of the size of government idea. We can do better.

To do so, we need to introduce direct measures of policy making and of economic effects. For economics theory dictates the choice of indicators. We have argued that unemployment shifts net preferences to the left and inflation shifts them to the right. Here, we examine those effects.

Since we are dealing with a unit root dependent variable (preferences), we employ the error correction framework for analysis. Error correction models assume that the major path of causality between two variables is that the explanatory variables create a dynamic equilibrium for the variable to be explained. ${ }^{62}$ Lacking a fixed mean to which it equilibrates, that is, a unit root variable is thought to equilibrate to a level dependent on the level of the causal series. Thus, when disturbed by some exogenous event or condition, it will tend to equilibrate, but to the dynamic target set by the explanatory variable, not to a fixed mean. The evidence for such dynamic equilibration is in two forms (1) that significant linear relationships are observed between the level of the explanatory series and change in the dependent series (the 'long-term' effects of Table 4), and (2) the error correction phenomenon, that changes in the dependent variable are negatively related to its previous deviations from dynamic equilibrium. ${ }^{63}$

We begin the analysis of economic effects in Table 4. There, in the column labelled 'Economics', we observe the long-term (and short-term) effects of unemployment and inflation on the first differences of preferences. We expect positive long-term effects for unemployment and negative ones for inflation. That is what can be seen in Table 4. But the effects are weak. The error correction is at the margin of significance, the unemployment effect right on the line $(p<0.052)$, and the inflation long-term effect is correctly signed but not significant. Predicting first differences is a very challenging task, and therefore it is hard to know whether an adjusted $R^{2}$ of 0.16 represents success or failure. Overall, we have a hint that economics matters for preferences, but the evidence is far from conclusive.

We do, however, also have two indicators of policy making that might add to our story and permit a more general test of Christopher Wlezien's thermostatic theory. We measure the benefit side of government with government expenditures as a proportion of GDP. ${ }^{64}$ The cost side of government is measured with average income tax. ${ }^{65}$ For both measures,

${ }^{62}$ Walter Enders, Applied Econometric Time Series (Hoboken, N.J.: Wiley, 2004), chap. 6; Jeffrey M. Wooldridge, Introductory Econometrics: A Modern Approach (Mason, Ohio: Thomson, South Western, 2006), chap. 18; Peter Kennedy, A Guide to Econometrics (Oxford: Blackwell, 2008), chap. 19.

${ }^{63}$ Short-term relationships between $\Delta x$ and $\Delta y$ may also be observed, but are relatively uncommon with unit root dependent series.

${ }^{64}$ We were unable to find a single measure of government expenditure as a proportion of GDP for the whole period 1950-2005. Therefore, we collected a series of overlapping indicators from a variety of sources and used the extraction algorithm to estimate a single series. The longest single-source period was found in G. White and H. Chapman, 'Long-term Trends in Public Expenditure', Economic Trends, 408 (1987), pp. 124-8; but we also used HM Treasury, OECD and Eurostat. These resulting series explained: 86.85 per cent of the variation in the data had a mean of 39.64 and a standard deviation of 3.42. The complete original dataset, together with the extraction output, is available from the authors on request.

${ }^{65}$ The measure of average income tax is based on analyses carried out by Frances Lynch and her colleagues at the University of Westminster. It measures average income tax levels for specified 'typical' individuals (see Paul Johnson, Frances Lynch and John Geoffrey Walker, 'Income Tax and Elections in Britain, 1950-2001', Electoral Studies, 24 (2005), 393-408). One of the most striking features of debates about tax in Britain is the extent to which debate resolves around income tax, even though it generates a 
TABLE $4 \quad$ Predicting Change in Preferences (Error Correction Models)

\begin{tabular}{|c|c|c|c|c|}
\hline Variable & Economics & Size of government & Both sets & Removing inflation \\
\hline \multicolumn{5}{|l|}{ Unemployment } \\
\hline Short-term & $\begin{array}{c}-0.09 \\
(0.33)\end{array}$ & & $\begin{array}{c}-0.52 \\
(0.45)\end{array}$ & $\begin{array}{c}-0.68 \\
(0.38)\end{array}$ \\
\hline Long-term & $\begin{array}{c}0.15 \\
(0.09)\end{array}$ & & $\begin{array}{l}0.41 * * \\
(0.16)\end{array}$ & $\begin{array}{l}0.47^{* *} \\
(0.14)\end{array}$ \\
\hline \multicolumn{5}{|l|}{ Inflation } \\
\hline Short-term & $\begin{array}{c}-0.03 \\
(0.09)\end{array}$ & & $\begin{array}{c}0.05 \\
(0.10)\end{array}$ & \\
\hline Long-term & $\begin{array}{c}-0.09 \\
(0.08)\end{array}$ & & $\begin{array}{c}-0.09 \\
(0.10)\end{array}$ & \\
\hline \multicolumn{5}{|c|}{ Average income tax } \\
\hline Short-term & & $\begin{array}{c}0.00 \\
(0.24)\end{array}$ & $\begin{array}{c}0.38 \\
(0.26)\end{array}$ & $\begin{array}{c}0.39 \\
(0.25)\end{array}$ \\
\hline Long-term & & $\begin{array}{c}-0.13 \\
(0.14)\end{array}$ & $\begin{array}{c}-0.38^{*} \\
(0.16)\end{array}$ & $\begin{array}{c}-0.40^{* *} * \\
(0.15)\end{array}$ \\
\hline \multicolumn{5}{|l|}{ Gov't expenditure } \\
\hline Short-term & & $\begin{array}{c}-0.37 \\
(0.25)\end{array}$ & $\begin{array}{c}0.07 \\
(0.30)\end{array}$ & $\begin{array}{c}0.18 \\
(0.27)\end{array}$ \\
\hline Long-term & & $\begin{array}{c}0.02 \\
(0.15)\end{array}$ & $\begin{array}{c}-0.17 \\
(0.21)\end{array}$ & $\begin{array}{c}-0.25 \\
(0.18)\end{array}$ \\
\hline Error correction & $\begin{array}{c}-0.11 \\
(0.07)\end{array}$ & $\begin{array}{c}-0.17 \\
(0.11)\end{array}$ & $\begin{array}{c}-0.39 * * \\
(0.12)\end{array}$ & $\begin{array}{c}-0.38 * * * \\
(0.11)\end{array}$ \\
\hline Intercept & $\begin{array}{c}5.55 \\
(4.32)\end{array}$ & $\begin{array}{c}10.11 \\
(10.33)\end{array}$ & $\begin{array}{l}32.38 * * * \\
(12.68)\end{array}$ & $\begin{array}{l}34.62 * * * \\
(11.90)\end{array}$ \\
\hline$N$ & 55 & 51 & 51 & 51 \\
\hline Adjusted $R^{2}$ & 0.16 & 0.01 & 0.18 & 0.20 \\
\hline
\end{tabular}

${ }^{*} p<0.05, * * p<0.01, * * * p<0.00$.

we expect negative long-term effects. Bigger government, that is, should push preferences to the right.

What we observe in Table 4 instead is explanatory failure. The adjusted $R^{2}$ of 0.01 tells us what we would also see from the coefficients, that we just have no evidence that (at least taken by itself) the size of government predicts preferences. These outcome variables are perhaps a step too far down the causal chain. They result from the cumulated policies of many governments over a very long span of time and do not necessarily tell us the recent drift of policy making, which may be more influential in driving preferences. With a product moment correlation between them of 0.75 , multicollinearity also impedes observing separate effects.

We consider a model which includes both sets of variables in the third column. Here, it becomes clear that both sets are required for a well-specified model. With a better model fit $\left(R^{2}=0.18\right)$, the long-term effect of unemployment emerges as a highly significant cause

(F'note continued)

relatively small proportion of government revenue. We have been provided with the data for male single industrial workers only. It is clear from Figure 2 in Johnson et al., 'Income Tax and Elections in Britain', that this correlates very well with average tax levels for married industrial workers too. These estimates are available only up to 2001 , with the consequence that $N$ falls to 51 . 
of preference changes as does long-term average taxes. The multicollinear government spending indicator remains correctly signed but non-significant. And inflation, as before, is correctly signed but not powerful enough to attain statistical significance.

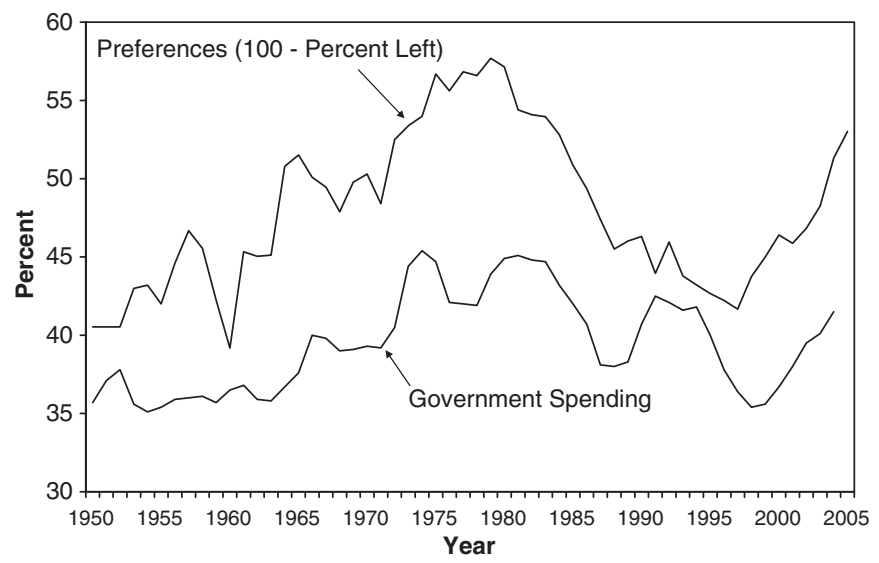

Fig. 4. The relationship between preferences for government activity and public expenditure Note: The preference series is reversed (100-left) to measure right sentiment.

The error correction specification, predicting first differences instead of the level of a series, combined with indicator multicollinearity, can lead to under-appreciation of the true strength of relationships. For another and simpler look at the data, we graph preferences against government spending in Figure 4. This time reversed to indicate right sentiment (i.e., 100 - left), it is quite clear in the graph that government spending and Conservative sentiment move in tandem $(r=0.75)$. Conservative governments, by cutting government spending, and Labour ones, by increasing it, both seem to sow the seeds of their own demise in policy making. The observed empirical fact of cycles of party control of government may now be seen as the expected outcome of governments pursuing their policy goals instead of heeding the moderating signal of public opinion. It is regularly observed that electorates often express the view that it is time for a change and that there seems to be a political pendulum at work. In this view, however, the pendulum is neither exogenous nor a valence issue but instead the predictable result of macro politics.

For a final test, we remove inflation from the specification and re-estimate the remainder of the terms. This results in strengthening both the unemployment and average tax long-term effects and improving the fit slightly to 0.20 . What we now know is that preferences are in a dynamic relationship with unemployment rates and with the size of government (with either indicator separately or average taxes jointly). That means that those two variables set an appropriate target level for preferences. And it tells us that when actual preferences move away from that target, they tend to correct back to it fairly rapidly. The estimated error correction rate $(0.38)$ tells us that almost 40 per cent of any deviation of preferences from the target rate in either direction is corrected within one year. ${ }^{66}$ Public preferences do

\footnotetext{
66 We have two alternative paths by which preferences might be related to levels of government spending and taxing. In one, preferences at earlier times affected election results and altered the control of government. So current spending may be a positive function of preferences at various lags. The thermostatic hypothesis introduces a different path. Current electorates react to the current and previous size of government mix
} 
respond to the size of government and to the state of the national economy. Ivor Crewe's observation that British elections are a matter of 'the economy and public services, stupid' seems to apply equally to preferences. ${ }^{67}$ And since the British state provides things that are in the United States provided by the market, this apparent difference from the United States makes some sense.

\section{SO WHAT? A FIRST LOOK AT PREFERENCES AND ELECTIONS}

A natural reaction to the results in the previous section is, so what? While we believe that preferences are important things to study in themselves, most readers are interested in them only in so far as they influence election outcomes. ${ }^{68}$ In this penultimate section, we examine briefly the relationship between preferences and elections. Before we do so, however, it is worth noting that there are some reasons not to expect a direct relationship between opinion and elections. Politicians are generally smart operators with a real incentive to learn about voters. If opinion is shifting, they are likely to respond and close the distance if at all possible (though they may face tight ideological constraints). As modellers, moreover, we face a series of obstacles. If spatial theories of elections are to be believed, electoral outcomes are driven by the distance between parties and the average or median voter. To construct a model of election outcomes, therefore, we need both a valid measure of party positions and some way of mapping voters and parties onto the same scale. This is a large task and one that we must necessarily postpone to another paper. ${ }^{69}$

Nevertheless, the preference series displayed in Figure 2 provides an interesting perspective on election outcomes. As David Butler has suggested, elections 'have registered the change of mood that events and political rhetoric have wrought, month by month, in the voters' minds. ${ }^{70}$ It is clear, however, that changes in preferences often long pre-date election outcomes. Both Mrs Thatcher's victory in 1979 and New Labour's triumph in 1997 are fully anticipated in the series. Nevertheless, it seems that preferences in 1979 (the year of Mrs Thatcher's first election) were not very different, for example, from those in 1974 (the year of Labour's two narrow victories). ${ }^{71}$ James Callaghan's

\footnotetext{
(F'note continued)

negatively. As government grows, they move to the right in response. As it declines, they move to the left. So when we observe a statistical connection between them, are we observing a web of endogeneity or can the two be sorted out? They differ in two important respects, which is helpful to sorting out causality claims. In timing, the logic requires the first path to associate changes in government only with lagged values of preferences. It is previous elections that put the current government in power. The thermostatic effect is the reverse; the electorate cannot react to changes in government until those changes have occurred, and therefore current preferences should reflect only previous policy. The second difference is the important matter of sign. One relationship, preferences $\rightarrow$ elections $\rightarrow$ policy, is positive; the other, policy $\rightarrow(-)$ preferences, is negative. Thus, the data can help sort out alternative interpretations. The sign and time order that we observe supports only the second, thermostatic, interpretation. We cannot rule out that the first path might exist. But if it does, it is too weak to leave behind evidence.

${ }^{67}$ Ivor Crewe, 'Now relax, it's a dead cert', New Statesman, 12 February 2001. See also Anthony King, 'Why Labour Won - At Last', in Anthony King, ed., New Labour Triumphs: Britain at the Polls, 1997 (Chatham, N.J.: Chatham House, 1998), pp. 177-207.

68 Stimson, Public Opinion in America, p. 98.

69 See Erikson et al., The Macro Polity, chap. 7.

70 David Butler, 'Reflections on British Elections and Their Study', Annual Review of Political Science, 1 (1998), 451-64, p. 455.

71 Labour actually obtained a lower share of the vote in February 1974 but obtained 301 seats to the Conservatives' 296. It obtained a tiny majority of just five seats in the subsequent election of October 1974.
} 
fatalism in spring 1979 may have reflected not only his (then recent) experiences during the Winter of Discontent, but the cumulative realization that public support for government activity had been eroded over the preceding thirty years.

Equally, preferences in 1997 (the year of New Labour's victory) do not look so very different from those five years earlier (when the Conservative party won a fourth consecutive victory). This latter finding may help explain why the electorate turned against the Conservatives so quickly - and so decisively - after the 'Black Wednesday' crisis in September 1992. Kenneth Newton suggested that the 1992 election campaign was in many ways a contest between 'caring' (Labour) and 'competence' (Conservative). ${ }^{72}$ It may simply be that many had voted Conservative in April 1992 despite their ideological dispositions. Many voters did 'care' about unemployment and the state of the public services but concluded that the Conservatives would be more 'competent' when it came to managing the economy than their Labour rivals. If this is true, then many voted Conservative with a heavy heart and may have felt like fools when Britain was forced to leave the ERM in September 1992. What may have hitherto been missing from accounts of 'Black Wednesday' is the observation that the electorate's 'hearts' were with Labour in 1992, though many were undoubtedly eventually ruled by their 'heads' and voted Conservative. Equally, while David Sanders is clearly correct in arguing that New Labour's victory in 1997 owed much to its move to the centre between 1992 and 1997, it also owed a great deal to the shift in preferences that had happened by $1992 .^{73}$

To bring the story up to date, it appears that some of Labour's losses in 2001 and 2005 may well be due to shifts in preferences. We know that preferences fell from around 58 in 1997 to approximately 49 points in 2005 (presumably as a result of the massive increases in spending and taxation following on from Gordon Brown's comprehensive spending review in August 2000). ${ }^{74}$ The Comparative Manifesto Project (CMP) analyses suggest that Labour moved left slightly between 1997 and 2001 and again between 2001 and $2005 .^{75}$ These shifts in party position were not large, but - when coupled with the drift to the right in preferences documented in Figure 2 - it seems plausible to suggest that Labour's losses may owe something to the increasing 'distance' between themselves and the electorate. ${ }^{76}$ To be sure, they may also be the result of a diminished valence advantage and the negative effects of the Iraq War. The evidence from our preference series, however, certainly hints at an additional proximity factor. And the reasons for this increased distance were movement by both the party and the electorate.

In due course, we hope to produce a single model of election outcomes for the period between 1950 and 2005. This will represent the closest thing approximating to a general model of elections that has yet been produced in Britain. It may then be possible to run simulations that will help resolve nagging questions, such as whether New Labour's shift to 'the centre' was necessary for it to win in 1997. As we have noted, however, that will require the imposition of some additional assumptions and is, therefore, a matter for further research.

72 Kenneth Newton, 'Caring and Competence', in Anthony King, ed., Britain at the Polls, 1992 (Chatham, N.J.: Chatham House, 1992).

73 David Sanders, 'The New Electoral Battleground', in Anthony King, ed., New Labour Triumphs: Britain at the Polls (Chatham, N.J.: Chatham House, 1998), p. 217.

${ }^{74}$ Polly Toynbee and David Walker, Did Things Get Better? An Audit of Labour's Successes and Failures (London: Penguin Books, 2001), p. 104.

75 Information provided by Judith Bara (Queen Mary and Westfield College, University of London).

76 See John Bartle, The New British Politics: Election Update (Harlow: Longman, 2005), p. 22. 


\section{CONCLUSIONS}

In recent years, political scientists are rightly concerned with replication and the need to demonstrate that empirical generalizations hold across time and space. ${ }^{77}$ It is heartening, therefore, that this article has provided corroboration of studies of the US macro polity. ${ }^{78}$ It has, for example, demonstrated that it is possible to track shifts in the political centre in Britain between using hard evidence drawn from survey data rather than - as was so often the case in the past - informed speculation. It has also demonstrated that - just as in the United States - the centre appears to move over long periods of time and that it moves in response to government activity. And it has gone beyond these US studies by examining the role of taxation and spending. When unemployment has risen or the share of the national wealth devoted to public spending has declined, the electorate has, on average, moved left. When taxes and spending have increased, the electorate has, on average shifted right. This provides support for Christopher Wlezien's thermostatic conception of public opinion generalized across the whole of government activity. ${ }^{79}$ It also provides an explanation of the 'costs of ruling': the tendency of governments to lose support whatever the state of the economy. ${ }^{80}$ This may be partly the result of governing parties following their ideological convictions about the scope of government activity. It will certainly be interesting to see whether these findings hold in other European countries and whether government spending has the same effect in the United States.

Our findings suggest that students of political behaviour should pay greater attention to those large-scale movements of opinion that occur over the long haul. It is all too easy to dismiss minor changes in survey marginal responses, but when these take place across a wide range of specific issues, they may tell us that something important is under way. ${ }^{81}$ Movements in public preferences may provide clues about both the likely direction of policy and electoral outcomes (though this is a matter for future research). These sorts of macro-level analyses provide an interesting and - to our minds - compelling alternative perspective to the more familiar micro-level studies. And, quite unlike such individuallevel studies, they permit us to examine the origins of those preferences and their relation to real or objectively measured causes, such as the economy.

Taken as a whole, these findings also provide support for the proposition that one can agree that the average citizen is not particularly informed, not particularly thoughtful, and not particularly attentive, but still find these characteristics emerge in the aggregate. ${ }^{82}$ The apparent responsiveness of preferences to government activity does something to salvage the reputation of the electorate. Our analyses provide clear evidence for the proposition that the electorate - when taken as an aggregate whole - is responsive to real outcomes. ${ }^{83}$

77 Gary King, 'Replication Replication', PS: Political Science and Politics, 3 (1995), 443-99.

78 Erikson et al., The Macro Polity, chaps 6 and 7.

79 Wlezien, 'The Public as Thermostat' and 'Patterns of Representation'.

${ }^{80}$ Martin Paldam, 'The Distribution of Election Results and Two Explanations of the Costs of Ruling', European Journal of Political Economy, 2 (1986), 5-24; Martin Paldam and Peter Skott, 'A Rational Voter Explanation of the Cost of Ruling', Public Choice, 83 (1995),159-72; Peter Naanstead and Martin Paldam, 'The Costs of Ruling', in Han Dorussen and Michael Taylor, eds, Economic Voting (London: Routledge, 2002), pp. 17-44.

81 Stimson, Public Opinion in America and Tides of Consent.

82 Erikson et al., The Macro Polity, p. 5.

83 Converse, 'Popular Representation and the Distribution of Information'. 
The political centre is a concept of enormous analytical importance and the estimates provided here can be used in a wide range of research. In our own research, we intend to provide more analyses of the dimensions underlying the preferences. ${ }^{84} \mathrm{We}$ will assess the impact of party proximity to the political centre on aggregate vote share (and possibly approval of the government's record). Ultimately, of course, we also wish to assess the quality of representation by determining the relationship between preferences and government activity. Only then will we be able to assess whether there is indeed a necessary relationship between what the public wants and what they actually get.

${ }^{84}$ John Bartle, Sebastian Dellepiane and James A. Stimson, 'The Dimensionality of British Political Preferences, 1950-2005' (paper presented at the 5th ECPR General Conference, Potsdam, 2009). 